\title{
Computer Assisted Language Learning and EFL Teachers' Literacy: A Case in Iran
}

\author{
Behrouz Jamalvandi ${ }^{1}$, Hossein Sadeghi ${ }^{1} \&$ Hassan Soleimani ${ }^{1}$ \\ ${ }^{1}$ School of English Language Teaching, Payame Noor University, Tehran, Iran \\ Correspondence: Behrouz Jamalvandi, School of English Language Teaching, Payame Nour University, Tehran, \\ Iran. Tel: 98-212-245-5005. E-mail: behrouzjamalvandi@gmail.com
}

Received: August 3, 2016

Accepted: October 24, 2016 Online Published: January 12, 2017

doi:10.5539/ijel.v7n1p201

URL: http://dx.doi.org/10.5539/ijel.v7n1p201

\begin{abstract}
Computer assisted language learning (CALL) literacy is an issue of great concern not sufficiently dealt with in the literature of language teaching and learning. This study examines CALL literacy by Iranian EFL teachers. Reviewing the literature and some models of computer, information, and technology literacy, to collect the data, a questionnaire in Likert scale composed of four sections of computer mediated communication (CMC) tools, online information literacy, multimedia literacy, and basic computer skills was utilized. Following the data analysis by SPSS package, the findings showed Iranian EFL teachers' moderate level of CALL literacy; however, their literacy on $\mathrm{CMC}$ tools was below the satisfactory level. Further, there was a significant relationship between the teachers' literacy and their academic degree, yet the relationship between their CALL literacy and their teaching experience as well as the difference between the teachers' literacy and gender was found insignificant. The study has implications for EFL teachers in educational systems supporting CALL-based pedagogy.
\end{abstract}

Keywords: CALL literacy, CMC tools, multimedia literacy, online information literacy

\section{Introduction}

The ubiquity of information and communication technology (ICT), its various services, and its penetrating into every corner of today's life is irrefutable. Digital forms of information and communication have transformed "what it means to work, study, research, express oneself, perhaps even to think" (Littlejohn, Beetham, \& McGill, 2012, p. 1). Likewise, in educational settings, the impact of new technology is conspicuously observable and dramatically on the rise although it is still not "normalized" (Bax, 2003). Holding a pivotal function in the structure of education in general and more particularly in computer assisted language learning (CALL), ICT demands that EFL/ESL teachers reinforce and deepen their literacy so as to be capable of coping with the requirements of today's educational world. The very concept of teachers' literacy has recently gained considerable attention in academic circles (See e.g., Barton, 2001; Gee, 2000; Lamy \& Hampel, 2007). Underlying the impossibility of isolating literacy from economic, social and technological aspects, Kress (2003) resorts to two outstanding elements:

the broad move from the now centuries-long dominance of writing to the new dominance of the image and, on the other hand, the move from the dominance of the medium of the book to the dominance of the medium of the screen (p. 1).

As far as CALL goes, teachers' literacy keeps a distance from its traditional definition pertaining, as Pegrum (2009) contends, to print-literacy, monolingualism, monoculturalism, and rule-governed forms of language and takes on a new conceptualization, which encompasses a wider array of skills and calls for more intricate demands on the part of EFL/ESL teachers. To put it another way, the introduction of new forms of technology in smart schools, the extensive application of both synchronous and asynchronous computer mediated communication (CMC) tools including Wikies, blogs, MOOs, emails, writeboards, MOODLE, podcast, Hot Potatos, and other devices (See e.g., Donaldson \& Haggstrom, 2006; Erben, Ban, \& Castenada, 2009; Thomas, 2009) accompanied by copious access to online sources have all given teachers' literacy a totally different and demanding concept. The significance carried by teachers' literacy in technology-dominated era and more technically in association with CALL served the main impetus to approach the issue with reference to Iranian EFL teachers. This inquiry accordingly targets at discovering how far Iranian EFL teachers hold literacy in 
tandem with CALL. The following questions were addressed through this investigation:

1) Are Iranian EFL teachers literate as far as CALL is concerned?

2) Are Iranian EFL teachers literate considering online interactions ( $\mathrm{CMC}$ tools)?

3) Are Iranian EFL teachers literate with respect to handling online information?

4) Are Iranian EFL teachers literate with reference to multimedia literacy?

5) Are Iranian EFL teachers literate as far as basic computer knowledge is concerned?

6) Does gender of Iranian EFL teachers signify any difference in their CALL literacy?

7) Does academic degree of Iranian EFL teachers show any relationship with their CALL literacy?

8) Does teaching experience of Iranian EFL teachers have any relationship with their CALL literacy?

\section{Literature Review}

\subsection{Theoretical Background}

Literacy has come under different terms in the literature: "digital literacy" (Gilster, 1997), "electronic literacy" (Warshauer, 1999), "techno-literacy" (Erben, 1999), "new literacies" (Lankshear \& Knobel, 2003), "media literacy" (Semali \& Pailliotet, 1999), and "multiple literacies" (Pierce, 2002). A taxonomy by Warshauer (2002) differentiated four electronic literacies, namely "computer literacy" dealing with being at ease while keyboarding and operating computer, "information literacy" pertaining to locating and evaluating online information, "multimedia literacy" in relation to sounds and images, and "computer-mediated communication literacy" on teachers' knowledge of how online interactions are formed by individuals and groups.

The intricacy attached to the term teachers' literacy with respect to CALL can be elucidated by ecological and sociocultural (SCT) perspectives (Lantolf, 2000; van Lier, 2004; Vygotsky, 1978) and complexity theory (Larsen-Freeman, 1997; Waldrop, 1992). According to van Lier, "since ecology studies organisms in their relations with the environment, ecology is a contextualized or situated form of research" (p. 3). Actually, he highlights the complexity existing in our relations with a dynamic environment, or more exactly a situated context, which, as he elaborates, is non-linear or emergent, value-laden, critical, variable, diverse, and active. It can accordingly be said that relying on ecological perspective, one can envisage teachers who would act in a world convoluted by many agents and even teachers act as components adding more to this complexity.

In the same vein, SCT gives crucial significance to functioning in context or situations of cultural, institutional, and historical considerations (Wertsch, Del Rio, \& Alvarez, 1995). Central to SCT is mediation, which is realized by others, self, or artifacts (Lantolf, 2000) and that mediation has turned far more complex. Teachers play the role of mediators in the interactions shaped in the complex environment of CALL. Further, as Lamy \& Hampel (2007) put it, presently to be an effective CALL teacher, it would not suffice to solely depend on our expertise rather we will need to identify strategies to make online learning more facilitated and drive learners to apply those strategies. Therefore, no longer are teachers the mere distributors of knowledge, rather they are in momentary and steady connection with the applicants in a multi-dimensional context.

Back to the theoretical foundations, to create a link between teachers' literacy, CALL, and complexity theory, it sounds reasonable to think of teachers acting in a system represented by a collective behavior as the consequence of interactions among elements in the system in a "complex, dynamic, non-linear, self-organizing, open, emergent, sometimes chaotic, and adaptive [manner]" (Larsen-Freeman, 1997, p. 4). These characteristics that specify the complexity of any system in the world could be generalizable to teachers' literacy, making it a more intricate definition than ever. No longer are teachers living in a static environment and the very dynamic nature of their career with respect to CALL evokes technical knowledge, computer knowledge, knowledge on online infrastructures developed for educational purposes and the multidirectional interactions.

\subsection{Empirical Studies on CALL Literacy}

A simple online search does suffice to witness the scope of literacy and its association with new technology and more exclusively its significance in CALL, having inspired countless research articles and books over the past years. A group of research studies accomplished on CALL and teachers' literacy in Iran and overseas are reported below.

Reflecting on teachers' computer literacy, Son, Robb, \& Charismiadji (2011) conducted a study in Indonesia. They showed that Indonesian teachers did not hold wide competence in using CALL. The participants in the study were proved to possess poor knowledge and application of databases and CMC tools. With respect to major hindrances affecting the use of computer at schools, Son et al. (2011) arrived at teachers' inadequate 
computer skills and dearth of facilities in this regard.

Correos (2014) studied teachers' ICT literacy and application ELT in the context of Spain. The results indicated that teachers, to a great extent, were of high literacy as far as primary computer skills were concerned. The teachers, however, acted moderately with respect to running an operating program via $\mathrm{CD}$ as well as regarding multitasking. Considering systems' security and maintenance, they were found to have poor literacy. Moreover, no competency was reported on installing programs on the part of the Spanish teachers. They also proved to be moderately literate in web-skills like using browsing and downloading and in using email. Likewise, the study revealed the teachers' unsatisfactory performance in multimedia tasks including creating PowerPoint. The same held true when considering online-mediated tasks like instant messenger, chat, and blogging. The main factors thwarting utilizing technology in language teaching, according to Correos (2014), was inadequate resources and facilities.

Dashtestani (2014) carried out an investigation on computer literacy among Iranian EFL teachers focusing on challenges and barriers. He concluded that teachers' computer literacy was not commensurate to execute CALL. Further, as to the barriers to enriching Iranian EFL teachers' literacy, Dashtestani pinpointed factors of inadequate implementation of teaching training programs, absence of support from authorities to contribute to enhancing teachers' literacy, and shortage of time to help teachers' literacy ameliorate.

Dealing with Iranian EFL teachers' perception of CMC tools, Sadeghi, Rahmani, \& Doosti (2014) arrived at the conclusion that majority of Iranian EFL teachers hold a positive view toward CMC tools. The point, however, is that there still exists a gap between this positive attitude and teachers' actual implementation of CMC tools in language classrooms. Rahimi \& Yadollahi (2011b) reported on ICT application in EFL classes in Iran. Their study showed that Iranian EFL teachers made the most use of software, Microsoft word, printer, educational websites, search engines, email services and CD players for educational purposes. Nonetheless, the frequency of utilizing digital portable tools in classes exceeded that of computer and the Internet applications.

Reviewing the literature on the relationship between Iranian teachers' CALL literacy and their academic degree shows that a number of investigations have addressed this aspect and demonstrated that teachers with higher degrees, i.e., M.A. and Ph.D. holders, make more use of ICT in their profession (Aghajani \& Zamani, 2012; Rahimi \& Yadollahi, 2011b; Zadeh Rahim, Hoseini \& Malekmohammadi, 2014).

The evidence from the previous studies on the relationship between gender and teachers' ICT utilization among Iranian teachers supports the fact that gender plays no significant role in this regard (Rahimi \& Yadollahi, 2011a, 2011b; Zadeh Rahim et al., 2014). In non-Iranian contexts, the same findings could be observed. Using a dynamic model, Markauskaite (2006) examined the issue of gender and teachers' ICT literacy and reported no significant role for gender in relation to teachers' ICT literacy. Nevertheless, the counter evidence comes from an experimental study with over five hundred in-service teachers in Nigeria (Agbatogun, 2009). The findings of the research endorsed the significant part gender plays in teachers' overall literacy. Similarly, Saleh Mahdi \& Sa'ad Al-Dera (2013) reported the significant difference between Saudi Arabian EFL teachers in terms of their gender and ICT application.

Studies conducted on the relationship between Iranian teachers' teaching experience and their ICT use have demonstrated that there is a negative correlation between these two variables. In other words, teachers with longer experience are less enthusiastic to apply ICT in their career (Aghajani \& Zamani, 2012; Rahimi \& Yadollahi, 2011a). Different findings were reported by Saleh Mahdi \& Sa'ad Al-Dera (2013). They found no significant relationship between Saudi Arabian EFL teachers and their experience.

\section{Methodology}

\subsection{Participants}

The target population of this study was Iranian highschool EFL teachers. They were randomly selected from among different schools including state and non-state schools, those run by boards of trustees and the ones affiliated to universities. The size of the sample in this inquiry reached 140 English teachers. They came from a range of teaching experience as well as different academic degrees (Table 1). 
Table 1. Profile of respondents

\begin{tabular}{lll}
\hline Variables & $\mathrm{N}$ & $\%$ \\
\hline 1. Gender & & \\
Male & 8 & 41.4 \\
Female & 82 & 58.6 \\
Total & 137 & 97.9 \\
No answer & 3 & 2.1 \\
\hline 2. Education & & \\
B.A. & 77 & 55 \\
M.A. & 47 & 33.6 \\
Ph.D & 11 & 7.9 \\
Total & 135 & 96.4 \\
No answer & 5 & 3.6 \\
\hline 3. Teaching experience & & \\
$0-10$ years & 56 & 40 \\
$11-20$ years & 55 & 39.3 \\
$21-30 \&$ over & 29 & 20.7 \\
Total & 140 & 100 \\
\hline
\end{tabular}

\subsection{Instrument}

This inquiry was basically a descriptive survey attempt. To accumulate the required data, a questionnaire (See Appendix A) composed of four sections with 58 items was devised. It was in Likert scale ranging from poor to excellent. The questionnaire was grounded on covering a number of investigations on CALL, literacy and technology (American Library Association, 2000; Donaldson \& Haggstrom, 2006; Erben, Ban, \& Castenada, 2009; Lankshear \& Knobel, 2003; Potter, 2012; Son, Robb, \& Charismiadji, 2011; Thomas, 2009; Valdez, 2000; Warshauer, 2002). The four sections included in this questionnaire elicited data from the sample on basic computer skills literacy, multimedia literacy, online interaction literacy, and information literacy. To guarantee the reliability of the questionnaire, Cronbach alpha was run in Statistical Package for Social Science (SPSS) software version 22 and the output showed 0.90 , suggesting an optimal level of the internal consistency. Further, to validate the questionnaire, factor analysis was computed by feeding the data into Linear Structural Relations (LIZREL) software. According to Soltani Tirani (1999) and Bentler (1980), the more RMSEA tends to zero, the better the model is. As another index, if the proportion of the value of Chi-square to that of df yields a value smaller than 0.3 , the model is considered as acceptable. As Figure 1 demonstrates, the model meets the conditions to be taken as an acceptable one (MSREA $=0.000$, Chi-square $/ \mathrm{df}=0.96)$.

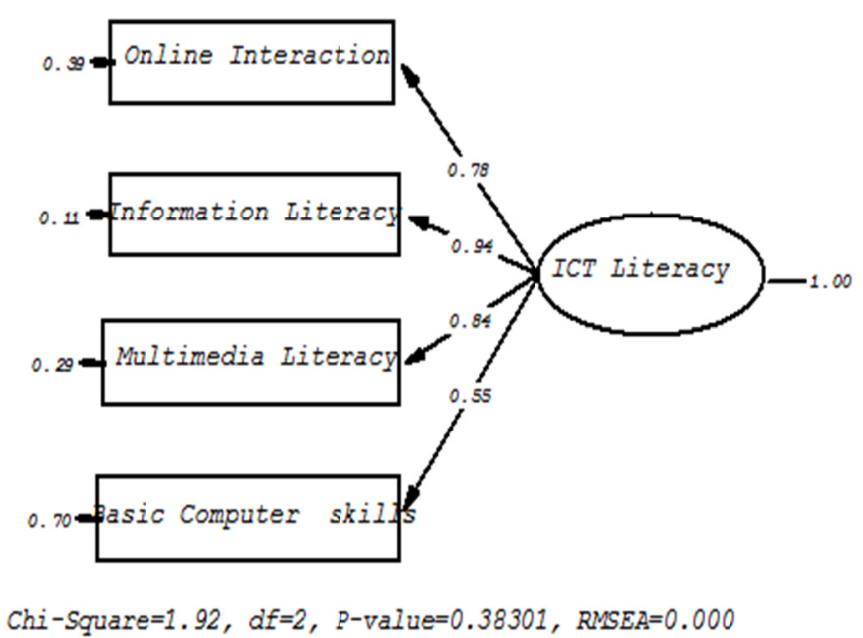

Figure 1. Factor analysis for checking validity of the instrument

\subsection{Procedure}

The process of delivering the questionnaire to the participants and receiving their feedback lasted for about two 
months (Sept.-Dec., 2015). One hundred questionnaires were emailed to EFL teachers, out of which 40 were returned. At the same time, as to those in reach, as many as $100 \mathrm{EFL}$ teachers were asked to fill out a hard copy of the questionnaire.

\subsection{Data Collection and Analysis}

When the data were gathered both via emails and hard copies of the questionnaire, the analysis was initiated by feeding the data into SPSS 22. In so doing, both descriptive and inferential statistics were applied. As to the former, measures of central tendency (i.e., median, and mean) and measures of variability (standard deviation) were computed. As to the latter, independent t-test, correlation and Chi-square were worked out. The results of the analysis are presented in the subsequent section.

\section{Results}

To appraise Iranian EFL teachers' overall CALL literacy, descriptive statistics was run by SPSS. The three-choice Likert scale including poor, good and excellent were recorded as 1, 2 and 3. As Table 2 depicts, Iranian EFL teachers' CALL literacy was 2.15 which falls between good and excellent levels of literacy. As another measure, the value of the median by 2.13 approximates to that of the mean, signifying the fact scores are close to the mean and thus having a normal distribution of the data. To check for the dispersion of the scores, standard deviation was computed. It was shown to be .34 , which is a small value considering the value of mean (2.15) and this fact points to the homogeneity of the scores.

Table 2. Iranian EFL teachers' CALL literacy

\begin{tabular}{llll}
\hline $\mathrm{N}$ & Mean & Median & $\mathrm{SD}$ \\
\hline 140 & 2.15 & 2.13 & .35 \\
\hline
\end{tabular}

In addition to descriptive statistics, inferential statistics was worked out. To see whether Iranian EFL teachers are literate as far as CALL is concerned, Chi-square was run. As Table 3 shows, since the Sig. value is smaller than $p$ value $(.000<0.05)$, we can claim that Iranian EFL teachers are CALL literate; therefore, the null hypothesis is rejected.

Table 3. Chi-square computed for Iranian EFL teachers' CALL literacy

Note. The significance level is .05.

\begin{tabular}{lll}
\hline Test & Sig. & Decision \\
\hline One-Sample Chi-Square Test & .000 & Reject the null hypothesis \\
\hline level is .05. & &
\end{tabular}

As stated earlier, CALL literacy in this research comprised four subsections including online interactions, information literacy, multimedia literacy, and basic computer skills. To investigate whether Iranian EFL teachers are literate with reference to online interactions or CMC tools, descriptive statistics was run. Table 4 shows that Iranian EFL teachers are proved to be literate in terms of online interactions (Mean=1.9). The value falls between poor and good levels of literacy with more tendency to good choice. The value of median by 1.94 which is close to the value of mean confirms the normal distribution of the data. Further, the obtained value of standard deviation by .40 supports the homogeneity of the data.

Table 4. Iranian EFL teachers' online interactions (CMC tools) literacy

\begin{tabular}{llll}
\hline $\mathrm{N}$ & Mean & Median & $\mathrm{SD}$ \\
\hline 140 & 1.90 & 1.94 & .40 \\
\hline
\end{tabular}

Iranian EFL teachers' literacy on online interactions was examined by computing Chi-square test. As the value of $\mathrm{Sig}$. is smaller than $p$ value $(.001<.05)$, it is true to state that Iranian EFL teachers are literate as far as online interactions is concerned (Table 5). 
Table 5. Chi-square computed for Iranian EFL teachers' online interactions (CMC tools) literacy

\begin{tabular}{lll}
\hline Test & Sig. & Decision \\
\hline One-Sample Chi-Square Test & .001 & Reject the null Hypothesis \\
\hline
\end{tabular}

Note. The significance level is .05.

The second fragment of CALL literacy to investigate in case of Iranian EFL teachers was information literacy. The results of computation of descriptive statistics (Table 6) revealed that the participants were literate in association with information literacy. This fact is endorsed by the obtained value of mean by 2.1 falling between good and excellent levels of literacy. Moreover, the value of median by 2.0 which stands close to the value of mean signifies the normal distribution of the data. As to the dispersion of the scores, standard deviation was computed and its smaller value by .38 when compared with that of mean showed that the data were homogeneous.

Table 6. Iranian EFL teachers' information literacy

\begin{tabular}{llll}
\hline $\mathrm{N}$ & Mean & Median & $\mathrm{SD}$ \\
\hline 140 & 2.10 & 2.05 & .385 \\
\hline
\end{tabular}

Examining Iranian EFL teachers' Information literacy was carried out by running Chi-square as well. As Table 7 illustrates, Iranian EFL teachers were proved to be literate with respect to information literacy. This fact comes from the value of Sig. which is smaller than $p$ value $(.000<.05)$, resulting in rejecting the null hypothesis.

Table 7. Chi-square computed for Iranian EFL teachers' information literacy

\begin{tabular}{llll}
\hline Test & Sig. & Decision \\
\cline { 2 - 4 } One-Sample Chi-Square Test & .000 & Reject the null hypothesis \\
\cline { 2 - 4 } Note. The significance level is .05. & &
\end{tabular}

Another segment of CALL literacy in the present inquiry dealt with multimedia literacy. The result of analysis of the data showed that Iranian EFL teachers were literate in this regard (Table 8). The value of mean by 2.0 went beyond good level of literacy moving toward excellent level of literacy. The value of median by 2.1 which approximates to the value of mean denotes the normal distribution of the data. Regarding the dispersion of the scores, the small value of standard deviation hitting .44 suggests the homogeneity of the data.

Table 8. Iranian EFL teachers' multimedia literacy

\begin{tabular}{llll}
\hline $\mathrm{N}$ & Mean & Median & $\mathrm{SD}$ \\
\hline 140 & 2.08 & 2.11 & .44 \\
\hline
\end{tabular}

Iranian EFL teachers' literacy on multimedia was appraised by running Chi-square test. As Table 9 demonstrates, the value of Sig. is smaller than $p$ value $(.000<0.05)$ meaning that null hypothesis is rejected. That is, Iranian EFL teachers were literate from the perspective of multimedia literacy.

Table 9. Chi-square computed for Iranian EFL teachers' multimedia literacy

Note. The significance level is .05 .

\begin{tabular}{lll}
\hline Test & Sig. & Decision \\
\hline One-Sample Chi-Square Test & .000 & Reject the null Hypothesis \\
\hline ance level is .05. & &
\end{tabular}

The fourth component of CALL literacy was basic computer skills. Scrutinizing whether Iranian EFL teachers are literate considering basic computer skills confirmed the fact that they are highly literate in this respect. The value of mean by 2.5 residing between good and excellent levels of literacy supports this claim. Further, the normality of distribution of the data can be elicited by referring to the value of median by 2.6 , which is close to the value of mean. Regarding the dispersion of the scores, the smaller value of standard deviation by .44 with respect to the value of mean confirmed the homogeneity of the data (Table 10). 
Table 10. Iranian EFL teachers' basic computer skills

\begin{tabular}{llll}
\hline $\mathrm{N}$ & Mean & Median & $\mathrm{SD}$ \\
\hline 140 & 2.52 & 2.62 & .44 \\
\hline
\end{tabular}

Iranian EFL teachers' Literacy in the area of basic computer skills was also statistically studied through computing Chi-square test. As Table 11 illustrates, since the value of Sig. is smaller than that of $p(000 .<.05)$, it is safe to state that Iranian EFL teachers are literate on basic computer skills hence the null hypothesis is rejected.

Table 11. Chi-sqaure computed for Iranian EFL teachers' basic computer skills

Note. The significance level is .05.

\begin{tabular}{lcl}
\hline Test & Sig. & Decision \\
\hline One-Sample Chi-Square Test & .000 & Reject the null hypothesis \\
\hline
\end{tabular}

This study investigated the role of gender in association with Iranian EFL teachers' CALL literacy. To do so, treating the data as quasi-interval, we ran t-test. As Table 12 portrays, since the value of Sig. exceeds that of $p$ $(\mathrm{df}=.943, .347>0.05)$, we can say that there is no significant difference between the gender of Iranian EFL teachers and their CALL literacy.

Table 12. Independent samples test for Iranian EFL teachers' gender and their CALL literacy

\begin{tabular}{|c|c|c|c|c|c|c|c|c|c|}
\hline & \multicolumn{2}{|c|}{$\begin{array}{l}\text { Levene's Test for } \\
\text { Equality of Variances }\end{array}$} & \multicolumn{7}{|c|}{ T-test for Equality of Means } \\
\hline & \multirow[t]{2}{*}{$\mathrm{F}$} & \multirow[t]{2}{*}{ Sig. } & \multirow[t]{2}{*}{$\mathrm{df}$} & \multirow{2}{*}{\multicolumn{2}{|c|}{$\begin{array}{l}\text { Sig. } \\
\text { 2-tailed) }\end{array}$}} & \multirow[t]{2}{*}{ MD } & \multirow[t]{2}{*}{ SED } & \multicolumn{2}{|c|}{$\begin{array}{l}95 \% \text { Confidence Interval of the } \\
\text { Difference }\end{array}$} \\
\hline & & & & & & & & Lower & Upper \\
\hline $\begin{array}{l}\text { Equal variances } \\
\text { Assumed }\end{array}$ & 2.350 & .128 & .943 & 135 & .347 & 3.33472 & 3.53471 & -3.65585 & 10.32529 \\
\hline
\end{tabular}

Note. MD denotes Mean Difference, SDD denotes Standard Error Difference.

Another variable researched by this study was the relationship between Iranian EFL teachers' academic degree and their CALL literacy. Running Pearson correlation signified the significant correlation between the participants' degrees and their literacy. As Table 13 shows, the value of Sig. is smaller than $p$ value $(.002<0.50)$.

Table 13. Iranian EFL teachers' academic degree and their CALL literacy

\begin{tabular}{llll}
\hline & & CALL literacy & Academic degree \\
\hline CALL literacy & Pearson Correlation & 1 & .156 \\
& Sig (2-tailed) & & .002 \\
& $\mathbf{N}$ & 140 & 135 \\
\hline Academic degree & Pearson Correlation & .156 & 1 \\
& Sig (2-tailed) & .002 & \\
& $\mathbf{N}$ & 135 & 140 \\
\hline
\end{tabular}

The relationship between Iranian EFL teachers' teaching experience and their CALL literacy was investigated applying Pearson correlation. As Table 14 shows, no significant relationship was found between these two variable as the value of Sig. surpassed $p$ value $(.652>0.05)$. 
Table 14. Iranian EFL teachers' teaching experience and their CALL literacy

\begin{tabular}{llll}
\hline & & Teaching experience & CALL literacy \\
\hline Teaching experience & Pearson Correlation & 1 & .042 \\
& Sig (2-tailed) & & .652 \\
& N & 118 & 118 \\
\hline CALL literacy & Pearson Correlation & .042 & 1 \\
& Sig (2-tailed) & .652 & 140 \\
\hline
\end{tabular}

\section{Discussion and Conclusion}

This research aimed at examining Iranian EFL teachers' literacy in connection with CALL. It further explored the relationship between the teachers' gender, academic degree and teaching experience and CALL literacy. The data was gathered through a questionnaire either emailed or handed to Iranian EFL teachers from different parts of the country.

Q1: Are Iranian EFL teachers literate as far as CALL is concerned?

The results of this study indicated that Iranian EFL teachers are literate considering overall CALL literacy. Yet, the level of their CALL literacy was found to be average. This finding is consistent with studies carried out by Correos (2014) and Rahimi \& Yadollahi (2011b) but is dissimilar to findings demonstrated by Dashtestani (2014) and Son et al. (2014). The lack of compromise on EFL teachers' level of literacy both in Iran and non-Iranian context suggests that this issue demand further research. Further, this discrepancy here might be for the still-present gap between EFL teachers and today's digital world. That is, computer technology in language teaching has not reached its normalization. The other point we should bear in mind is that cultural, institutional and historical factors (Wertsh et al., 1995) can facilitate or debilitate the enhancement of CALL literacy across the world.

Q2. Are Iranian EFL teachers literate considering online interactions (CMC tools)?

In line with previous inquiries (Correos, 2014; Sadeghi et al., 2014; Son et al., 2011), as far as Iranian EFL teachers' literacy on online interactions or CMC tools is concerned, the findings of this research study revealed that their literacy was not satisfactory. This can confirm the fact that the growing complexity of interconnectedness of various roles and factors in communication and its connection with language teaching, as argued previously with reference to ecological, SCT and complexity systems (Lantolf, 2000; Larsen-freeman, 1997; VanLier; 2004; Vygotsky, 1978), demands Iranian EFL teachers to ameliorate on this aspect either through participating in in-serving training courses or enhancing it individually.

Q3. Are Iranian EFL teachers literate with respect to handling online information?

This study dealt with another pertinent dimension of CALL literacy, namely online information literacy. It mainly focuses on finding and evaluating information and its sources easily, quickly, critically and effectively. Unlike the results of a study by Correos (2014), the findings of the present investigation showed that the teachers' literacy in this regard was above average and hence satisfactory enough. This could be a promising sign signifying the growth of Iranian EFL teachers in online world of information.

Q4. Are Iranian EFL teachers literate with reference to multimedia literacy?

Examining Iranian EFL teachers' multimedia literacy showed that their literacy on producing text, image and sound and using them critically and other related skills under multimedia literacy is average. Although the teachers were reported to hold multimedia literacy, their CALL literacy in this section needs improvement. This finding is inconsistent with Correos' (2014) report on Spanish EFL teachers' multimedia literacy found as poor.

Q5. Are Iranian EFL teachers literate as far as basic computer knowledge is concerned?

In harmony with previous research (Rahimi \& Yadollahi, 2011; Correos, 2014) the findings of this study on Iranian EFL teachers' literacy on basic computer skills including keyboarding, using CD-ROMs, file management and other skills displayed a high level of the teachers' level of literacy in this regard. The possible explanation for this result could be the fact that the teachers mostly access fully to computers and they have passed the time when English teachers had apprehension attached to using computer while teaching.

Q6. Does gender of Iranian EFL teachers signify any difference in their CALL literacy?

As to the role of gender in association with teachers CALL literacy, this study reported no difference for this 
variable just as the literature has shown it (Rahimi \& Yadollahi, 2011a, 2011b; Zadeh Rahim et al., 2014). However, considering non-Iranian contexts, this finding differs from the results displayed by Markauskaite (2006) and Saleh Mahdi \& Sa'ad Al-Dera (2013), supporting significant role for gender in ICT usage. This divergence residing in the role of gender and CALL literacy might be accounted for through further research.

Q7. Does academic degree of Iranian EFL teachers show any relationship with their CALL literacy?

Examining the relationship between the teachers' CALL literacy and their academic degree in this study showed a significant relationship between these two variables. Those with higher degrees are more willing to approach ICT in language teaching. The same finding has been reported earlier (Aghajani \& Zamani, 2012; Rahimi \& Yadollahi, 2011b; Zadeh Rahim et al., 2014).

Q8. Does teaching experience of Iranian EFL teachers have any relationship with their CALL literacy?

As far as Iranian EFL teachers' teaching experience and its relationship with their CALL literacy is concerned, the findings of the current research displayed no significant relationship in this regard. Previous research on this issue represents two different patterns. A group of studies have found a trade-off between teachers' CALL literacy and their teaching experience; the more experienced they are, the less they apply ICT (Aghajani \& Zamani, 2012; Rahimi \& Yadollahi, 2011a). Another line of research, as true about this inquiry, has shown no significant relationship between the two variables (Saleh Mahdi \& Sa'ad Al-Dera, 2013).

In a nutshell, Iranian EFL teachers were found to be moderately literate with reference to CALL. Nonetheless, some aspects of their literacy does require amelioration, specially the area of CMC tools. Further, no significant difference was reported for the teachers' CALL literacy and gender. The same result held true for Iranian EFL teachers' CALL literacy and their teaching experience. As to the teachers' degree and its relationship with CALL literacy, it was found that post graduate teachers make more utilization of ICT.

In accord with the findings of the current inquiry, as the result of exigencies of the new digital world, EFL teachers in Iranian educational system are highly recommended to boost their knowledge on applying CALL facilities in their career and particularly diverse online platforms and networks that can make teaching English more intriguing and effective.

\section{Limitations and Further Research}

As this researcher intended to collect data mainly through emailing the questionnaire to Iranian EFL teachers, the most problematic barrier to carry out this process was the fact that there were still a lot of EFL teachers who lacked emails or missed checking their emails regularly. This obstacle engendered sampling fewer number of EFL teachers than expected. Future research might encompass a far larger number of EFL teachers. Later it could be feasible to run experimental research studies on the impact of holding CALL courses based new framework in this study and scrutinize pertinent factors in association with Iranian EFL teachers.

\section{References}

Agbatogun, A. (2009). Gender Diversity and ICT Literacy among Nigerian In-Service Teachers. Gender and Behaviour, 7(2). http://dx.doi.org/10.4314/gab.v7i2.48703

Aghajani, H., \& Zamani, B. E. (2012). An investigation of the factors influencing the Internet usage by Engineering faculty members for doing scientific and research activities. Interdisciplinary Journal of Contemporary Research in Business, 3(11), 742-752.

American Library Association. (2000). Information Literacy Competency Standards for Higher Education. Retrieved from http://www.ala.org/acrl/ilcomstan

Barton, D. (2001). Directions for literacy research: Analysing language and social practices in a textually mediated world. Language and Education, 15(2\&3), 92-131. https://doi.org/10.1080/09500780108666803

Bax, S. (2003). CALL_past, present and future. System, 3, 13-28. https://doi.org/10.1016/S0346-251X(02)00071-4

Bentler, P. M. (1980). Multivariate analysis with latent variables: Causal modeling. Annual Review of Psychology, 31, 419-456. https://doi.org/10.1146/annurev.ps.31.020180.002223

Correos, C. (2014). Teachers' ICT Literacy and Utilization in English Language Teaching.ICT \& Innovations in Education. International Electronic Journal, 2(1), 1-25.

Dashtestani, R. (2014). Computer literacy of Iranian teachers of English as a foreign language: Challenges and obstacles. International Journal of Pedagogies and Learning, 9(1), 87-100. https://doi.org/10.1080/18334105.2014.11082022 
Donaldson, R. P., \& Haggstrom, M. A. (2006). Changing Language Education through CALL. New York: Routledge.

Erban, T., Ban, R., \& Cataneda, M. (2009). Teaching English Language Learners through Technology. Routledge: New York.

Erben, T. (1999) Constructing Learning in a Virtual Immersion Bath: LOTETeacher Education through Audiographics. In R. Debski \& M. Levy (Eds.), WORLDCALL: Global Perspectives on Computer-assisted Language Learning (pp. 229-248). Lisse: Swets and Zeitlinger.

Gee, J. (2000) The New Literacy Studies and the Social Turn. In D. Barton, M. Hamiltonand, \& R. Ivani (Eds.), Situated Literacies: Reading and Writing in Context (pp. 180-196). New York: Routledge. Retrieved from http://www.schools.ash.org.au/litweb/page300.html

Gilster, P. (1997). Digital Literacy. New York: Wiley and Computer Publishing.

Kress, G. (2003). Literacy in the New Media Age. London: Routledge. https://doi.org/10.4324/9780203164754

Lamy, M. N., \& Hampel, R. (2007). Online communication in language learning and teaching. New York: Palgrave Macmillan. https://doi.org/10.1057/9780230592681

Lankshear, C., \& Knobel, M. (2003). New literacies: Changing knowledge and classroom learning. Buckingham and Philadelphia: OUP.

Lantolf, J. P. (Ed.). (2000). Sociocultural theory and second language learning. Oxford: Oxford University Press.

Larsen-Freeman, D. (1997). Chaos/complexity science and second language acquisition. Applied Linguistics, 18, 141-165. https://doi.org/10.1093/applin/18.2.141

Littlejohn, A., Beetham, H., \& McGill, L. (2012). Learning at the digital frontier: a review of digital literacies in theory and practice. Journal of Computer Assisted Learning, 28(6), 547-556. https://doi.org/10.1111/j.1365-2729.2011.00474.x

Markauskaite, L. M. (2006). Gender issues in pre-service teachers' training: ICT literacy and online learning. Australasian Journal of Educational Technology, 22(1), 1-20. https://doi.org/10.14742/ajet.1304

Pegrum, M. (2009). Communicative networking and linguistic mashups on Web 2.0. In M. Thomas (Ed.). Handbook of Research on Web 2.0 and Second Language Learning (pp. 20-39). New York: Information Science Reference. https://doi.org/10.4018/978-1-60566-190-2.ch002

Pierce, L. V. (2002). Performance-based assessment: Promoting achievement for English language learners. ERIC/CLL News Bulletin, 26(1), 1-3. Washington, DC: ERIC Clearinghouse on Languages and Linguistics.

Potter, W. J. (2012). Media literacy. London: SAGE Publications, Inc.

Rahimi, M., \& Yadollahi, S. (2011a). Computer anxiety and ICT integration in English classes among Iranian EFL teachers. Procedia Computer Science, 3, 203-209. https://doi.org/10.1016/j.procs.2010.12.034

Rahimi, M., \& Yadollahi, S. (2011b). ICT Use in EFL Classes: A Focus on EFL Teachers' Characteristics. World Journal of English Language, 1(2), 17-29. https://doi.org/10.5430/wjel.v1n2p17

Sadeghi, B., Rahmany, R., \& Doosti , E. (2014). L2 teachers' reasons and perceptions for using or not using computer mediated communication tools in their classroom. Journal of Language Teaching and Research, 5(3), 663-673. https://doi.org/10.4304/jltr.5.3.663-673

Saleh Mahdi, H., \& Sa'ad Al-Dera, A. (2013). The impact of teachers' age, gender and experience on the use of information and communication technology in EFL teaching. English Language Teaching, 6(6), 57-67. https://doi.org/10.5539/elt.v6n6p57

Semali, L. M., \& Pailliotet, A. W. (Eds.). (1999). Intermediality the teachers' handbook of critical media literacy. Oxford: Westview Press.

Soltani Tirani, F. (1999). The application of causal analysis in social and behavioral science. Tehran: State Management.

Son, J. B., Robb, T., \& Charismiadji, I. (2011). Computer literacy and competency: A survey of Indonesian teachers of English as a foreign language. CALL-EJ, 12(1), 26-42.

Thomas, M. (Ed.). (2009). Handbook of research on Web 2.0 and second language learning. New York: Information Science Reference. 
van Lier, L. (2004). The ecology and semiotics of language learning: A sociocultural perspective. New York: Kluwer Academic Publishers. https://doi.org/10.1007/1-4020-7912-5

Vygotsky, L. S. (1978). Mind in society: The development of higher psychological processes. Cambridge, MA: Harvard University Press.

Waldrop, M. M. (1992). Complexity: The emerging science at the edge of order and chaos. New York: Simon \& Schuster.

Warschauer, M. (2002). A developmental perspective on technology in language education. TESOL Quarterly, 36(3), 453-475. https://doi.org/10.2307/3588421

Wertsch, J. V., Del Rio, P., \& Alvarez, A. (Eds.) (1995). Sociocultural studies of mind. Cambridge: CUP. https://doi.org/10.1017/CBO9781139174299

Zadeh Rahim, N., Hoseini, S. M., \& Malekmohammadi, I. (2014). Determining the factors affecting ICT adoption by Kermanshah agriculture vocational school teachers. Science Road Journal, 2(1), 13-20.

\section{Appendix A}

\section{Dear respondent!}

Thank you for your cooperation to fill out this questionnaire. After reading each question carefully, please tick your choice.

Gender: $\quad$ Male $\square \quad$ Female $\square$

Academic degree: $\quad$ B.A. $\square \quad$ M.A. $\square \quad$ Ph.D. $\square$

Length of teaching experience: .......years.

A. Online interactions (computer mediated communication tools) literacy:

1. How good are you at emailing? Poor $\square \quad$ Good $\square \quad$ Excellent $\square$

2. How good are you at blogging? Poor $\square \quad$ Good $\square \quad$ Excellent $\square$

3. How good are you at operating Wiki? Poor $\square \quad$ Good $\square \quad$ Excellent $\square$

4. How good are you at MOODLE? Poor $\square \quad$ Good $\square \quad$ Excellent $\square$

5. How good are you at MOO? Poor $\square \quad$ Good $\square \quad$ Excellent $\square$

6. How good are you at voice chatting? Poor $\square \quad$ Good $\square \quad$ Excellent $\square$

7. How good are you at videoconferencing? Poor $\square \quad$ Good $\square \quad$ Excellent $\square$

8. How good are you at podcasting? Poor $\square \quad$ Good $\square \quad$ Excellent $\square$

9. How good are you at vodcasting? Poor $\square \quad$ Good $\square \quad$ Excellent $\square$

10. How good are you at discussion boards? Poor $\square \quad$ Good $\square \quad$ Excellent $\square$

11. How good are you at writeboard? Poor $\square \quad$ Good $\square \quad$ Excellent $\square$

12. How good are you at smart phones? Poor $\square \quad$ Good $\square \quad$ Excellent $\square$

13. How good are you at Ovoo/Skype? Poor $\square \quad$ Good $\square \quad$ Excellent $\square$

14. How good are you at Facebook? Poor $\square \quad$ Good $\square \quad$ Excellent $\square$

15. How good are you at What's app? Poor $\square \quad$ Good $\square \quad$ Excellent $\square$

16. How good are you at Viber? Poor $\square \quad$ Good $\square \quad$ Excellent $\square$

17. How good are you at Telegram? Poor $\square \quad$ Good $\square \quad$ Excellent $\square$

18. How good are you at Line? Poor $\square \quad$ Good $\square \quad$ Excellent $\square$

B. Information literacy:

1. How good are you at finding and evaluating online information?

Poor $\square \quad$ Good $\square \quad$ Excellent $\square$

2. How good are you at critically evaluating information and its sources? 
Poor $\square \quad$ Good $\square \quad$ Excellent $\square$

3. How good are you at determining the domain of the required information?

Poor $\square \quad$ Good $\square \quad$ Excellent $\square$

4. How good are you at merging the selected information with your previous knowledge?

Poor $\square \quad$ Good $\square \quad$ Excellent $\square$

5. How good are you at effectively applying the information in teaching?

Poor $\square \quad$ Good $\square \quad$ Excellent $\square$

6. How good are you at identifying keywords, synonyms and relevant terms in association with the required information?

Poor $\square \quad$ Good $\square \quad$ Excellent $\square$

7. How good are you at organizing knowledge to be accessed effectively?

Poor $\square \quad$ Good $\square \quad$ Excellent $\square$

8. How good are you at recognozing the value and difference in formats of information (multimedia, databases, web, adiovisual, book)?

Poor $\square \quad$ Good $\square \quad$ Excellent $\square$

9. How good are you at identifying the target audience of the information?

Poor $\square \quad$ Good $\square \quad$ Excellent $\square$

10. How good are you at selecting among various technologies the most appropriate one for the task of extracting the needed information (e.g., copy/paste software functions, photocopier, scanner, audio/visual equipment, or exploratory instruments)?

Poor $\square \quad$ Good $\square \quad$ Excellent $\square$

11. How good are you at examining and comparing information from various sources in order to evaluate reliability, validity, accuracy, authority, timeliness, and point of view or bias?

Poor $\square \quad$ Good $\square \quad$ Excellent $\square$

12. How good are you at utilizing computer and other technologies (e.g. spreadsheets, databases, multimedia, and audio or visual equipment) for studying the interaction of ideas and other phenomena?

Poor $\quad$ Good $\square \quad$ Excellent $\square$

13. How good are you at comparing new knowledge with prior $\mathrm{k}$ at nowledge to determine the value added, contradictions, or other unique characteristics of the information?

Poor $\square \quad$ Good $\square \quad$ Excellent $\square$

14. How good are you at participating in class-sponsored electronic communication forums designed to encourage discourse on the topic (e.g., e-mail, bulletin boards, chat rooms)?

Poor $\square \quad$ Good $\square \quad$ Excellent $\square$

15. How good are you at identifying and discussing issues related to free vs. fee-based access to information?

Poor $\square \quad$ Good $\square \quad$ Excellent $\square$

16. How good are you at identifying and discussing issues related to privacy and security in both the print and electronic environments?

Poor $\square \quad$ Good $\square \quad$ Excellent $\square$

17. How good are you at identifying plagiarism or manipulation of information?

Poor $\square \quad$ Good $\square \quad$ Excellent $\square$

C. Multimedia literacy:

1. How good are you at producing media text including text, image and sound?

Poor $\square \quad$ Good $\square \quad$ Excellent $\square$

2. How good are you at analyzing and interpreting media text including text, image and sound?

Poor $\square \quad$ Good $\square \quad$ Excellent $\square$ 
3. How good are you at teaching study skills or watching critically?
Poor $\square$
Goodᄆ
Excellent $\square$

4. How good are you at using modern technology including computer to process and produce information?

Poor $\quad$ Good $\square \quad$ Excellent $\square$

5. How good are you at inferring cause-effect relationships?

Poor $\square \quad$ Good $\square \quad$ Excellent $\square$

6. How good are you at identifying impact of deviation, stereotypes,commercials and aggression in visual media?

Poor $\square \quad$ Good $\square \quad$ Excellent $\square$

7. How good are you at interpreting and creating visual images?

Poor $\quad$ Good $\square \quad$ Excellent $\square$

8. How good are you at using media critically?

Poor $\square$ Good $\square \quad$ Excellent $\square$

\section{Basic computer skills:}

1. How good are you at using Web sites to supplement your learning?

Poor $\square \quad$ Good $\square \quad$ Excellent $\square$

2. How good are you at using computer for learning purposes?

Poor $\square \quad$ Good $\square \quad$ Excellent $\square$

3. How good are you at using CD-ROMs to supplement your learning?

Poor $\quad$ Good $\square \quad$ Excellent $\square$

4. How good are you at using keyboard shortcuts?

Poor $\square \quad$ Good $\square \quad$ Excellent $\square$

5. How good are you at copying, cutting, and pasting text in a document?

Poor $\square$ Good $\square \quad$ Excellent $\square$

6. How good are you at changing font style and size in a document?

Poor $\square \quad$ Good $\square \quad$ Excellent $\square$

7. How good are you at minimizing, maximizing and moving windows on the desktop?

Poor $\square \quad$ Good $\square \quad$ Excellent $\square$

8. How good are you at performing file management including deleting and renaming files?

Poor $\quad$ Good $\square \quad$ Excellent $\square$

9. How good are you at using a 'search' command to locate a file?

Poor $\square$ Good $\square \quad$ Excellent $\square$

10. How good are you at moving a file from a hard drive to a USB drive?

Poor $\square$ Good $\square \quad$ Excellent $\square$

11. How good are you at printing a document using a printer?

Poor $\square \quad$ Good $\square \quad$ Excellent $\square$

12. How good are you at sending and receiving attachments through e-mail messages?

Poor $\square$ Good $\square \quad$ Excellent $\square$

13. How good are you at downloading and saving files from the Web (e.g., text, graphic, PDF files)?

Poor $\square \quad$ Good $\square \quad$ Excellent $\square$

14. How good are you at searching for information online using a Web search engine?

Poor $\square \quad$ Good $\square \quad$ Excellent $\square$ 
15. How good are you at changing monitor brightness and contrast?

\section{Poor $\square \quad$ Good $\square \quad$ Excellent $\square$}

16. How good are you at install a software program?

Poor $\square \quad$ Good $\square \quad$ Excellent $\square$

\section{Copyrights}

Copyright for this article is retained by the author(s), with first publication rights granted to the journal.

This is an open-access article distributed under the terms and conditions of the Creative Commons Attribution license (http://creativecommons.org/licenses/by/4.0/). 